\title{
Pathogenicity of some local entomopathogenic fungus isolates on the cotton leafworm larvae, Spodoptera littoralis (Boisd.) (Lepidoptera: Noctuidae)
}

\author{
Funda Şahin ${ }^{*}$ (I) and Yusuf Yanar
}

\begin{abstract}
Background: Pathogenicity of the entomopathogenic fungi (EPF), isolated from soil samples collected from Ordu Province, Turkey, was evaluated on the second-instar larvae of the cotton leaf worm Spodoptera littoralis (Boisd.) (Lepidoptera: Noctuidae) under laboratory conditions.

Results: Firstly, single-concentration response tests were conducted in order to determine the efficacy of the 64 isolates on S. littoralis larvae at the concentration of $1 \times 10^{8} \mathrm{conidia} / \mathrm{ml}$. The five isolates displaying the highest mortality rates in single-concentration response tests, ORU-50, ORM-40, ORP-13, ORP-27 and ORM-48 (which included Beauveria bassiana, Metarhizium brunneum and Clonostachys rogersoniana), were subjected to concentration-response tests at the concentrations of $1 \times 10^{5}-1 \times 10^{9}$ conidia/ml. The lowest $L C_{50}$ and $L C_{90}$ values were recorded at ORP- 27 with $1.68 \times 10^{7}$ and $4.60 \times 10^{8}$ conidia/ml, respectively, followed by ORP-13 and ORM-40.
\end{abstract}

Conclusions: Accordingly, it was found that M. brunneum isolates were more effective than B. bassiana and C. rogersoniana against $S$. littoralis larvae. ORP-27, ORP-13 and ORM-40 of M. brunneum isolates can be a potential biological control agent used against $S$. littoralis larvae.

Keywords: Entomopathogenic fungi, Spodoptera littoralis, Metarhizium brunneum, Beauveria bassiana, Clonostachys rogersoniana, Pathogenicity

\section{Background}

The cotton leaf worm, Spodoptera littoralis (Boisd.) (Lepidoptera: Noctuidae), is a polyphagous pest that damages several crop plants and spreads in the Mediterranean, Aegean, and Southeastern Anatolia regions of Turkey, and many countries of the temperate zone (CABI 2021). Numerous studies showed that there have been many reports of effective parasitoids, predators, and pathogens in controlling this pest.

*Correspondence: funda.memisoglu@gop.edu.tr

Department of Plant Protection, Faculty of Agriculture, Tokat

Gaziosmanpasa University, 60250 Tokat, Turkey
Entomopathogenic fungi (EPF) have an important place among pathogens, playing a role in controlling many pest groups naturally. Their infection process begins with the penetration stage following contact of fungal propagules to the host cuticle. After this stage, the fungus attacks the host through vegetative growth, using their enzymes or toxins, and causes damage or death of their host (OrtizUrquiza and Keyhani 2013).

EPF have an advantage over other insect pathogens like entomopathogenic bacteria and viruses as they can infect their host not only through diet, but also directly from the spiracles and insect cuticle. EPF can control their host pests specifically without harming biocontrol agents, do not pose a risk on mammals, do not cause pollution of 
the environment as encountered with pesticide applications, do not cause insect resistance, and provide longterm struggle with the host (Wan 2003). They can lead to death directly or weaken vital activities of their host by means of consuming the nutrient content, causing mechanical damage to host tissues and producing some toxic metabolites (Kulkarni 2015). Some abiotic factors such as temperature and humidity play an important role in the germination and development of fungi and may limit the pathogenicity of even a strong pathogen under insufficient conditions (Mishra et al. 2015). Efficacy of different EPF isolates varies from isolates/strain to another (even though in the same species) against the target host because their biological activities such as virulence, germination rate, mycelial growth, spores production and enzyme activity are different from each other (El Husseini 2019). Therefore, selecting and testing different EPF isolates with different characteristics increases the chance of getting a successful biocontrol agent for controlling host insects.

Various studies have reported that some EPF isolates including Beauveria bassiana, B. brongniartii, Metarhizium anisopliae, M. flavoviride, Paecilomyces fumosoroseus and Lecanicillium lecanii showed different activities at varying rates against $S$. littoralis larvae (Kılıç et al. 2019). The aim of the present study was to evaluate pathogenicity of the EPF isolates against $S$. littoralis larvae under laboratory conditions.

\section{Methods}

\section{Rearing of Spodoptera littoralis larvae}

Spodoptera littoralis larvae were reared on artificial diet under the laboratory conditions of $25 \pm 1{ }^{\circ} \mathrm{C}$ and $65 \pm 5 \%$ (Güney et al. 2019). Emerged adults were fed on honey solution in impregnated cotton in plastic boxes $(36 \times 23 \mathrm{~cm})$. Egg masses were collected on paper band regularly and transferred into new storage boxes including artificial diet for maintaining the colony and for experimental uses. The second-instar larvae (L2) were used for testing the pathogenicity of the fungal isolates in the experiments.

\section{Fungal isolates}

In the experiment, 64 EPF isolates were isolated from soil samples taken from Ordu Province in Turkey in 2019-20 using the Galleria bait method (Zimmermann 1986). DNA extraction of isolated fungi was performed for the identification of the isolates. Then, the polymerase chain reaction (PCR) was carried out to genomic DNA amplify, using ITS4/ITS5 primers. Finally, the obtained PCR products were subjected to sequence analysis. As a result of the sequence analysis, it was determined that the isolates were 23 Beauveria bassiana, 11 Metarhizium brunneum, 8 M. anisopliae, 6 M. robertsii, 4 Purpureocillium lilacinum, 4 Clonostachys rogersoniana, 3 Fusarium solani, 1 Clonostachys rossmaniae, 1 Aspergillus flavus, 1 Cordyceps cicadae, 1 C. fumosorosea and 1 F. oxysporum isolates. All isolates were grown on potato dextrose agar (PDA) medium in incubator at $25 \pm 1{ }^{\circ} \mathrm{C}$ for $15-30$ days.

\section{Preparation of fungal inoculum}

To produce inoculum, the fungi were subcultured to PDA plates by conidial transfer. Fungal spores were harvested by scraping using scalpel to falcon tubes after getting sporulation by adding $10 \mathrm{ml}$ of $0.02 \%$ Tween 80 solution. The conidial suspension was mixed for 1-2 min and filtered through four layers of cheesecloths to eliminate hyphal fragments. The suspension was diluted to a concentration of $1 \times 10^{8}$ conidia/ml, using a hemocytometer. The isolates displaying the highest mortality rates as a result of single-concentration response tests were adjusted to $1 \times 10^{5}, 1 \times 10^{6} 1 \times 10^{7}, 1 \times 10^{8}$ and $1 \times 10^{9}$ conidia/ml by dilution with the same technique. All suspensions were stored at $+4{ }^{\circ} \mathrm{C}$ to be used within 3 days.

\section{Single-concentration response tests}

Second-instar larvae of $S$. littoralis were placed in petri dishes containing artificial diet and sprayed with $1 \times 10^{8}$ conidia/ml concentrations of all isolates. The larvae in control treatment were sprayed by $0.02 \%$ Tween 80 solution. Each treatment had a batch of 10 larvae and replicated six times. Mortality rates of the larvae were recorded daily from the 3rd day up to the 13th day of incubation.

\section{Concentration-response tests}

Second-instar larvae of $S$. littoralis were placed in petri dishes as noted above and sprayed with different spore concentrations $\left(1 \times 10^{5}, 1 \times 10^{6} 1 \times 10^{7}, 1 \times 10^{8}\right.$ and $1 \times 10^{9}$ conidia $\left./ \mathrm{ml}\right)$. Mortality rates of the larvae were recorded daily from the 3rd day up to the 13th day of incubation.

\section{Statistical analysis}

Average values of larvae mortality data were subjected to probit analysis for calculating $\mathrm{LC}_{50}$ and $\mathrm{LC}_{90}$. Data were processed by one-way analysis of variance (ANOVA), followed by Tukey's post hoc test for comparison of means using the SPSS (Statistical Package of Social Sciences) software version 22 .

\section{Results}

Single-concentration response tests

The results in Table 1 show the mortality percentages of S. littoralis larvae treated with $1 \times 10^{8}$ conidia/ml concentrations of each isolate. 
Table 1 Mortality \% of Spodoptera littoralis larvae treated with $1 \times 10^{8}$ conidia/ml concentrations of the EPF isolates

\begin{tabular}{|c|c|c|c|c|c|c|c|c|c|c|c|}
\hline \multirow[t]{2}{*}{ Species } & \multirow[t]{2}{*}{ Isolates } & \multicolumn{4}{|c|}{$\begin{array}{l}\text { Mortality \% in days post- } \\
\text { treatment }\end{array}$} & \multirow[t]{2}{*}{ Species } & \multirow[t]{2}{*}{ Isolates } & \multicolumn{4}{|c|}{$\begin{array}{l}\text { Mortality \% in days post- } \\
\text { treatment }\end{array}$} \\
\hline & & 3 & 5 & 9 & 13 & & & 3 & 5 & 9 & 13 \\
\hline Control & 0 & 0 & 0 & 0 & 0 & B. bassiana & ORP-15 & 0 & 0 & 0 & 56.67 \\
\hline Beauveria bassiana & ORU-11 & 1.67 & 23.33 & 43.33 & 46.67 & M. robertsii & ORP-16 & 5 & 8.33 & 10 & 58.33 \\
\hline B. bassiana & ORU-21 & 1.67 & 15.3 & 53.48 & 64.55 & Metarhizium brunneum & ORP-17 & 0 & 0 & 0 & 68.33 \\
\hline B. bassiana & ORU-23 & 3.33 & 46.67 & 60 & 60 & M. brunneum & ORP-18 & 0 & 6.67 & 75 & 75 \\
\hline Metarhizium robertsii & ORU-25 & 16.67 & 60 & 60 & 60 & M. brunneum & ORP-22 & 0 & 21.67 & 90 & 90 \\
\hline M. robertsii & ORU-40 & 18.33 & 60 & 65 & 65 & B. bassiana & ORP-24 & 0 & 0 & 0 & 48.33 \\
\hline B. bassiana & ORU-50 & 49.09 & 98.33 & 100 & 100 & Paecilomyces lilacinum & ORP-26 & 0 & 0 & 1.67 & 83.33 \\
\hline B. bassiana & ORF-3 & 10 & 20 & 31.67 & 43.33 & M. brunneum & ORP-27 & 0 & 1.67 & 100 & 100 \\
\hline B. bassiana & ORF-8 & 4.85 & 21.52 & 78.79 & 78.79 & Clonostachys rogersoniana & ORP-29 & 4.17 & 4.17 & 3.52 & 10 \\
\hline B. bassiana & ORF-9 & 5 & 23.33 & 73.33 & 73.33 & M. anisopliae & ORP-30 & 5 & 45 & 71.67 & 71.67 \\
\hline B. bassiana & ORF-11 & 10 & 10 & 43.64 & 56.97 & Cordyceps fumosorosea & ORP-34-a & 1.82 & 5.64 & 32 & 32 \\
\hline B. bassiana & ORF-17 & 0 & 60 & 66.67 & 66.67 & M. brunneum & ORP-34-b & 1.67 & 3.33 & 30 & 55 \\
\hline B. bassiana & ORF-22-a & 16.67 & 29.7 & 53.94 & 67.27 & B. bassiana & ORP-35 & 5 & 5 & 45 & 58.33 \\
\hline B. bassiana & ORF-23 & 1.67 & 6.67 & 65 & 65 & P. lilacinum & ORP-36 & 3.33 & 6.67 & 10 & 23.33 \\
\hline B. bassiana & ORF-25 & 5 & 6.67 & 46.67 & 50 & M. brunneum & ORP-37 & 8.33 & 8.33 & 31.67 & 36.67 \\
\hline M. brunneum & ORF-30 & 1.67 & 13.33 & 38.33 & 38.33 & M. anisopliae & ORP-39 & 0 & 13.33 & 86.67 & 86.67 \\
\hline B. bassiana & ORF-42 & 1.67 & 35.76 & 68.79 & 68.79 & M. anisopliae & ORP-40 & 13.33 & 16.67 & 33.33 & 35 \\
\hline B. bassiana & ORF-43 & 0 & 3.33 & 64.39 & 67.73 & B. bassiana & ORP-46 & 0 & 3.33 & 45.91 & 50.91 \\
\hline M. anisopliae & ORM-8 & 14.85 & 39.85 & 70.45 & 72.12 & M. robertsii & ORP-48 & 0 & 6.67 & 68.33 & 73.33 \\
\hline Aspergillus flavus & ORM-14 & 3.33 & 5 & 60 & 61.67 & B. bassiana & ORG-1 & 0 & 0 & 30 & 30 \\
\hline P. lilacinum & ORM-21 & 9.39 & 19.39 & 58.94 & 58.94 & B. bassiana & ORG-2 & 1.67 & 1.67 & 33.33 & 33.33 \\
\hline B. bassiana & ORM-39 & 3.33 & 3.33 & 6.67 & 20 & C.rogersoniana & ORG-5 & 10 & 15 & 35 & 35 \\
\hline M. brunneum & ORM-40 & 50 & 98.33 & 98.33 & 98.33 & M. anisopliae & ORG-6 & 23.33 & 33.33 & 56.67 & 56.67 \\
\hline B. bassiana & ORM-45 & 54 & 66 & 76 & 76 & M. anisopliae & ORG-21 & 15 & 23.33 & 56.67 & 56.67 \\
\hline M. anisopliae & ORM-47 & 1.67 & 1.67 & 46.82 & 55.15 & C.rossmaniae & ORG-24 & 26.67 & 28.33 & 58.33 & 58.33 \\
\hline C. rogersoniana & ORM-48 & 66.67 & 85 & 91.67 & 91.67 & C.rogersoniana & ORG-35 & 23.33 & 28.33 & 63.33 & 63.33 \\
\hline B. bassiana & ORM-50 & 26.67 & 28.33 & 63.33 & 63.33 & M. robertsii & ORG-42 & 35 & 38.33 & 61.67 & 61.67 \\
\hline M. brunneum & ORP-1 & 18.33 & 28.33 & 33.33 & 43.33 & P. lilacinum & ORG-48 & 1.67 & 3.33 & 31.67 & 36.67 \\
\hline M. anisopliae & ORP-2 & 3.33 & 50 & 85 & 85 & Fusarium solani & ORM-7 & 5 & 11.67 & 30 & 30 \\
\hline M. robertsii & ORP-4 & 1.67 & 60 & 90 & 90 & F. solani & ORU-10 & 8.03 & 19.7 & 57.12 & 65.45 \\
\hline Cordyceps cicadae & ORP-9 & 5 & 5 & 43.33 & 65 & F. solani & ORU-39 & 0 & 1.67 & 46.67 & 58.33 \\
\hline M. brunneum & ORP-13 & 43.33 & 71.67 & 85 & 93.33 & Fusarium oxysporum & ORF-22-b & 3.33 & 10 & 43.33 & 46.67 \\
\hline M. brunneum & ORP-14 & 50 & 65 & 88.33 & 88.33 & & & & & & \\
\hline
\end{tabular}

According to the findings of the single-concentration response test, it was generally reported that all the tested isolates differed in their virulence to the larvae. Most of the isolates were not different from the control group for 3 days after treatment. However, ORP-13, ORP-14, ORM-48, ORU-50, ORM-40 and ORM-45 isolates belonging to Beauveria, Metarhizium and Clonostachys genera showed a mortality rate of around $50 \%$. Even though the mortality rates showed an increase for 5 days after treatment compared to 3 days, the most significant rise in mortality rates occurred on the 9th day of treatment; the mortality rate of over $50 \%$ was recorded in half of the isolates. Except for ORP-13, all the isolates had the highest mortality rates on the 13th day. Therefore, the isolates displaying the highest mortality rates ORU-50 (B. bassiana) (100\%), ORM-40 (M. brunneum) (98.33\%), ORM-48 (C. rogersoniana) (91.67\%), ORP-13 (M. brunneum) (93.33\%) and ORP-27 (M. brunneum) $(100 \%)$ were subjected to concentration-response tests $\left(1 \times 10^{5}-1 \times 10^{9}\right.$ conidia/ml $)$.

\section{Concentration-response tests}

The results in Table 2 show the mortality rates of S. littoralis larvae treated with different concentrations of the 
Table 2 Mortality \% of Spodoptera littoralis larvae treated with different concentrations of the five isolates displaying the highest mortality rates in single-concentration response tests

\begin{tabular}{|c|c|c|c|c|c|c|c|}
\hline \multirow[t]{2}{*}{ Isolates } & \multicolumn{7}{|c|}{ Mortality $\%$ in days post-treatment } \\
\hline & $\begin{array}{l}\text { Concentrations } \\
\text { (conidia/ml) }\end{array}$ & 3 & 5 & 7 & 9 & 11 & 13 \\
\hline Control & - & $0 a^{*}$ & Oa & Oa & Oa & Oa & Oa \\
\hline \multirow[t]{5}{*}{ ORU-50 Beauveria bassiana } & $1 \times 10^{5}$ & Oa & Oa & Oa & Oa & Oa & Oa \\
\hline & $1 \times 10^{6}$ & Oa & Oa & Oa & Oa & Oa & Oa \\
\hline & $1 \times 10^{7}$ & Oa & $1.51 a$ & $1.51 \mathrm{a}$ & $3.03 a$ & $7.57 a b$ & $7.57 \mathrm{a}$ \\
\hline & $1 \times 10^{8}$ & Oa & Oa & $1.51 \mathrm{a}$ & $33.18 a$ & $43.18 a b c$ & $43.18 \mathrm{ab}$ \\
\hline & $1 \times 10^{9}$ & Oa & Oa & $15.00 \mathrm{a}$ & $36.66 a$ & $50.00 \mathrm{bc}$ & $53.33 b$ \\
\hline \multirow{5}{*}{$\begin{array}{l}\text { ORM-40 } \\
\text { Metarhizium brunneum }\end{array}$} & $1 \times 10^{5}$ & Oa & Oa & $3.33 a$ & $3.33 a$ & $3.33 a$ & $6.66 a$ \\
\hline & $1 \times 10^{6}$ & $1.66 a$ & $1.66 \mathrm{a}$ & $1.66 a$ & $1.66 a$ & $16.06 a$ & $24.24 a b$ \\
\hline & $1 \times 10^{7}$ & $2.00 a$ & $2.00 a$ & $2.00 a$ & $2.00 a$ & $30.00 \mathrm{a}$ & $46.00 \mathrm{bc}$ \\
\hline & $1 \times 10^{8}$ & $2.00 \mathrm{a}$ & $2.00 a$ & $2.00 a$ & 18.00ab & $62.00 \mathrm{~b}$ & $64.00 \mathrm{~cd}$ \\
\hline & $1 \times 10^{9}$ & Oa & $0 a$ & $3.33 a$ & $50.30 \mathrm{~b}$ & $75.15 b$ & $80.15 d$ \\
\hline \multirow{5}{*}{$\begin{array}{l}\text { ORP-13 } \\
\text { M.brunneum }\end{array}$} & $1 \times 10^{5}$ & Oa & Oa & $\mathrm{Oa}$ & $0 \mathrm{a}$ & Oa & Oa \\
\hline & $1 \times 10^{6}$ & $1.66 a$ & $1.66 a$ & $1.66 a$ & $1.66 a b$ & $10.00 \mathrm{a}$ & $10.00 a$ \\
\hline & $1 \times 10^{7}$ & Oa & Oa & $1.66 a$ & $32.27 b c$ & $57.12 b$ & $58.78 b$ \\
\hline & $1 \times 10^{8}$ & $3.33 a$ & $5.00 a$ & $20.00 \mathrm{a}$ & $61.66 \mathrm{~cd}$ & $70.00 \mathrm{~b}$ & $70.00 \mathrm{~b}$ \\
\hline & $1 \times 10^{9}$ & 4.00a & $4.00 a$ & $60.00 \mathrm{~b}$ & $84.00 d$ & $84.00 \mathrm{~b}$ & $84.00 \mathrm{~b}$ \\
\hline \multirow{5}{*}{$\begin{array}{l}\text { ORP-27 } \\
\text { M.brunneum }\end{array}$} & $1 \times 10^{5}$ & $2.00 a$ & $2.00 a$ & $2.00 a$ & $2.00 a$ & $3.81 a$ & $3.81 a$ \\
\hline & $1 \times 10^{6}$ & $1.81 \mathrm{a}$ & $1.81 a$ & $3.81 \mathrm{a}$ & $3.81 \mathrm{a}$ & $3.81 \mathrm{a}$ & $3.81 \mathrm{a}$ \\
\hline & $1 \times 10^{7}$ & $5.00 a$ & $5.00 a$ & $12.22 \mathrm{a}$ & $43.28 b$ & $44.79 b$ & $49.79 b$ \\
\hline & $1 \times 10^{8}$ & Oa & Oa & $14.54 a$ & $76.91 \mathrm{c}$ & $84.72 c$ & $84.72 c$ \\
\hline & $1 \times 10^{9}$ & Oa & Oa & $16.00 \mathrm{a}$ & $78.00 \mathrm{c}$ & $88.00 \mathrm{c}$ & $88.00 \mathrm{c}$ \\
\hline \multirow{5}{*}{$\begin{array}{l}\text { ORM-48 } \\
\text { Clonostachys rogersoniana }\end{array}$} & $1 \times 10^{5}$ & Oa & Oa & Oa & $0 \mathrm{a}$ & Oa & Oa \\
\hline & $1 \times 10^{6}$ & $1.66 a$ & $1.66 a$ & $10.00 \mathrm{a}$ & $10.00 a$ & $10.00 \mathrm{a}$ & $10.00 \mathrm{a}$ \\
\hline & $1 \times 10^{7}$ & $1.66 a$ & $1.66 a$ & $28.33 a$ & 33.33ab & $48.33 b$ & $48.33 b$ \\
\hline & $1 \times 10^{8}$ & $1.66 \mathrm{a}$ & $3.33 a$ & $43.33 a$ & $61.66 \mathrm{bc}$ & $63.33 b$ & $63.33 b$ \\
\hline & $1 \times 10^{9}$ & Oa & $7.50 a$ & $32.95 a$ & $75.45 c$ & $75.45 b$ & $75.45 b$ \\
\hline
\end{tabular}

${ }^{*}$ Means in a column followed by the same letter for each isolate group are not statistically significant different $(P<0.05)$

five isolates displaying the highest mortality rates in single-concentration response tests.

According to the findings of the concentrationresponse test, it was indicated that mortality rates on larvae were not different than the control group on the 3-5 days post-inoculation. On the 7th day of treatment, the highest concentration-dependent mortality was observed in ORP-13, followed by ORM-48, even though the increase in mortality rate was dependent. The highest mortality rates were obtained at $1 \times 10^{9}$ conidia $/ \mathrm{ml}$ concentrations on the 9 th day post-treatment for ORP-13 and ORM-48, on the 11th day post-treatment for ORP27 . On the 13 th day post-inoculation, the mortality rates caused by $M$. brunneum isolates were around $80-88 \%$ and ORM-48 was also close to this percentage with a $75 \%$ mortality rate. On the other hand, B. bassiana isolate (ORU-50) caused the lowest mortality rate in concentration-response test (53\%). The mortality rate of the isolates generally increased with concentration increase although the isolates were ineffective on larvae at $1 \times 10^{5}$ and $1 \times 10^{6}$ conidia $/ \mathrm{ml}$ concentrations.

Data obtained from the dose-response tests were subjected to probit analysis. The concentrations which killed $50 \%\left(\mathrm{LC}_{50}\right)$ and $90 \%\left(\mathrm{LC}_{90}\right)$ of the population on the 13 th day of treatment and the analysis parameters are given in Table 3 . The lowest $\mathrm{LC}_{50}$ and $\mathrm{LC}_{90}$ values were recorded in ORP-27 with $1.68 \times 10^{7}$ and $4.60 \times 10^{8}$ conidia $/ \mathrm{ml}$, respectively. Accordingly, the most virulent isolate was determined as ORP-27, followed by ORP-13.

\section{Discussion}

Amer et al. (2008) reported higher mortality rates with the treatment of $1 \times 10^{5}$ and $1 \times 10^{6}$ conidia/ml concentrations and lower mortality rates with the treatment of $1 \times 10^{7}, 1 \times 10^{8}$ and $1 \times 10^{9}$ conidia/ml concentrations of B. bassiana isolates on S. littoralis larvae compared to the 
Table $3 L C_{50}$ and $L C_{90}$ values of the isolates against second-instar larvae of Spodoptera littoralis at 13 days after treatment

\begin{tabular}{|c|c|c|c|c|}
\hline Isolates & Slope \pm SE & $x^{2}$ & $\begin{array}{l}\mathrm{LC}_{50} \text { (conidia/ml) }(95 \% \text { Confidence limits } \\
\text { lower-upper) }\end{array}$ & $\begin{array}{l}\mathrm{LC}_{90} \text { (conidia/ml) }(95 \% \\
\text { Confidence limits } \\
\text { lower-upper) }\end{array}$ \\
\hline ORU-50 & $0.8333 \pm 0.05$ & 17.595 & $\begin{array}{l}7.65 \times 10^{7} \\
\left(1.09 \times 10^{7}-2.36 \times 10^{9}\right)\end{array}$ & $\begin{array}{l}7.38 \times 10^{9} \\
\left(5.28 \times 10^{8}-7.08 \times 10^{14}\right)\end{array}$ \\
\hline ORM-40 & $0.75 \pm 0.04$ & 1.945 & $\begin{array}{l}2.25 \times 10^{7} \\
\left(1.35 \times 10^{7}-3.83 \times 10^{7}\right)\end{array}$ & $\begin{array}{l}4.36 \times 10^{9} \\
\left(1.67 \times 10^{9}-1.59 \times 10^{10}\right)\end{array}$ \\
\hline ORM-48 & $0.8333 \pm 0.05$ & 18.708 & $\begin{array}{l}4.07 \times 10^{7} \\
\left(5.39 \times 10^{6}-6.25 \times 10^{8}\right)\end{array}$ & $\begin{array}{l}2.96 \times 10^{9} \\
\left(2.8 \times 10^{8}-2.85 \times 10^{13}\right)\end{array}$ \\
\hline ORP-13 & $0.8333 \pm 0.05$ & 25.070 & $\begin{array}{l}2.10 \times 10^{7} \\
\left(1.74 \times 10^{6}-3.04 \times 10^{8}\right)\end{array}$ & $\begin{array}{l}9.29 \times 10^{8} \\
\left(1.03 \times 10^{8}-1.13 \times 10^{13}\right)\end{array}$ \\
\hline ORP-27 & $1 \pm 0.06$ & 23.755 & $\begin{array}{l}1.68 \times 10^{7} \\
\left(1.97 \times 10^{6}-1.47 \times 10^{8}\right)\end{array}$ & $\begin{array}{l}4.60 \times 10^{8} \\
\left(6.92 \times 10^{7}-2.78 \times 10^{11}\right)\end{array}$ \\
\hline
\end{tabular}

present study. Contrary to this, Asi et al. (2013) recorded higher efficiency than these studies against S. litura larvae on the same dosages. In other study, a strain of $B$. bassiana showed high mortality rates with the treatment of $1 \times 10^{6}, 1 \times 10^{7}$ and $1 \times 10^{8}$ conidia/ml concentrations, whereas another strain had not caused mortality on $S$. littoralis larvae (El-Katatny 2010). Similarly, some researchers determined that $M$. anisopliae showed around $88-90 \%$ mortality rate at $2 \times 10^{6}$ and $1 \times 10^{7}$ conidia $/ \mathrm{ml}$ concentrations on $S$. littoralis larvae; nevertheless, the mortality rates of $M$. anisopliae on S. litura larvae were found below $5 \%$ even in the highest concentration (El Husseini 2019). In another study by Fite et al. (2020), $M$. anisopliae isolates showed a wide range of mortality rates between 20 and $70 \%$ on Helicoverpa armigera (Hubner) (Lepidoptera: Noctuidae) larvae. Several studies tested the efficacy of Clonostachys spp. against various target pests, yet no studies found on S. littoralis (Kim et al. 2020). These studies showed that Clonostachys spp. were not common in insects but may be possible in pathogens. Consequently, many studies on different target pests proved that different strains or isolates of the same fungal species even though using the same concentration may differ in virulence of the fungi (Fite et al. 2020).

Dhanapal et al. (2020) calculated the $\mathrm{LC}_{50}$ values of eight different $M$. anisopliae isolates on $S$. litura between $1.24 \times 10^{5}$ and $3.45 \times 10^{6}$ conidia/ml and concluded that the virulence of the fungus varied according to the strain. Asi et al. (2013) determined the $\mathrm{LC}_{50}$ value of a $B$. bassiana isolate on $S$. litura larvae as $1.11 \times 10^{7}$ conidia $/ \mathrm{ml}$ at 10th days. El Husseini (2019) calculated the $\mathrm{LC}_{50}$ and $\mathrm{LC}_{90}$ values of a $M$. anisopliae isolate as $6.2 \times 10^{4}$ and $1.4 \times 10^{7}$ conidia/ml, respectively, on $S$. littoralis larvae at 7 th days. The lethal concentration values in this study were lower than other previous studies on Spodoptera species and the present study; therefore, the death effects of this isolate were high. In contrast, El-Hawary and Abd
El-Salam (2009) determined the $\mathrm{LC}_{50}$ and $\mathrm{LC}_{90}$ values of a commercial B. bassiana isolate on $\mathrm{S}$. littoralis as $0.2 \times 10^{9}$ and $1.5 \times 10^{9}$ conidia/ml, respectively. The $\mathrm{LC}_{50}$ values were higher than other studies. These results can be interpreted that those local isolates may be more efficient on Spodoptera species than commercial isolates.

The mortality rates occurred at $1 \times 10^{8}$ conidia $/ \mathrm{ml}$ concentration in the concentration-response tests of the five isolates which were lower than in the single-concentration tests. Similarly, Çerçi (2010) also stated that the findings of the same concentration obtained from the single-concentration and concentration-response tests differ. These variations may be due to the difference in application date or the continuous passing of fungus cultures to purify and reproduce them. Butt and Goettel (2000) argued that when an isolate is to be used in biological activity tests, its virulence should be increased by passing it through an insect host before culturing on media.

Generally, it was found that Metarhizium spp. (especially $M$. brunneum) showed a high mortality rate on $S$. littoralis larvae, whereas $B$. bassiana isolates showed lower mortality rate than Metarhizium spp. Besides that, Cordyceps spp. and P. lilacinum isolates showed a weak activity on the larvae. C. rogersoniana species generally showed a low mortality rate, but one isolate of this species managed to control S. littoralis larvae. Similarly, Amer et al. (2008) reported that M. anisopliae and $M$. flavoviride were highly effective on S. littoralis, whereas $B$. bassiana and B. brongniartii showed the lowest rate. El-Katatny (2010) revealed that one strain of B. bassiana isolates caused a high mortality rate on $S$. littoralis larvae, while the others did not show virulence. Similarly, El-Hawary and Abd El-Salam (2009) argued that B. bassiana was more effective than $P$. fumosoroseus against $S$. littoralis. Contrary to these, Cirbin (2017) inferred that $B$. bassiana isolates were more effective on $S$. littoralis 
larvae than $M$. anisopliae ones. These findings confirm that different results can be obtained using different isolates of the same species as observed in the present study.

\section{Conclusions}

In conclusion, M. brunneum isolates (ORP-27, ORP-13 and ORM-40) had good potential as possible biocontrol agents against $S$. littoralis larvae. Additional studies to investigate the biological activity of the EPF isolates against $S$. littoralis and its natural enemies using various formulation techniques under field conditions are still needed.

\begin{abstract}
Abbreviations
S. littoralis: Spodoptera littoralis; S. litura: Spodoptera litura; B. bassiana: Beauveria bassiana; B. brongniartii: Beauveria brongniartii; M. anisopliae: Metarhizium anisopliae; M. brunneum: Metarhizium brunneum; M. flavoviride: Metarhizium flavoviride; C. rogersoniana: Clonostachys rogersoniana; P. fumosoroseus: Paecilomyces fumosoroseus; P. lilacinum: Purpureocillium lilacinum; PDA: Potato dextrose agar; PCR: Polymerase chain reaction; ITS: Internal transcribed spacer.
\end{abstract}

\section{Acknowledgements}

Not applicable.

\section{Authors' contributions}

FS performed the experiment, analysis of data and manuscript writing; YY contributed to technical assistance, analysis of data, supervision and manuscript writing. Both authors read and approved the final manuscript.

\section{Funding}

This research was funded by Tokat Gaziosmanpasa University Scientific Research Projects Coordination, project number 2020/18. The Scientific Research Projects Commission is a committee aimed to support scientific research in higher education institutions. The consumables used in this research project and service procurement covering primer synthesis and sequence analysis were financed by this commission.

\section{Availability of data and materials}

All data generated or analyzed during this study are included in this published article.

\section{Declarations}

Ethics approval and consent to participate

Not applicable.

\section{Consent for publication}

Not applicable.

\section{Competing interests}

The authors declare that they have no competing interests.

Received: 6 September 2021 Accepted: 23 November 2021

Published online: 28 November 2021

\section{References}

Amer MM, El-Sayed TI, Bakheit HK, Moustafa SA, El-Sayed YA (2008) Pathogenicity and genetic variability of five entomopathogenic fungi against Spodoptera littoralis. Res J Agric Biol Sci 4(5):354-367

Asi MR, Bashir MH, Afzal M, Zia K, Akram M (2013) Potential of entomopathogenic fungi for biocontrol of Spodoptera litura Fabricius (Lepidoptera: Noctuidae). J Anim Plant Sci 23(3):913-918
Butt TM, Goettel MS (2000) Bioassays of entomogenous fungi. In: Navon A, Ascher KRS (eds) Bioassays of entomopathogenic microbes and nematodes. CABI Publishing, UK

CABI (Centre for Agriculture and Bioscience International) (2021) Spodoptera littoralis (cotton leaf worm). https://www.cabi.org/isc/datasheet/51070. Accessed 21 Nov 2019

Çerçi FS (2010) Bazı fungus izolatlarının pamuk yaprakkurdu, Spodoptera littoralis (Boisd.) (Lepidoptera: Noctuidae), larvalarına ölüm etkilerinin belirlenmesi.) M.Sc. Thesis, Kahramanmaraş Sütçü İmam University, Kahramanmaraş, Turkey

Cırbın I (2017) Entomopatojen fungus izolatlarının Spodoptera littoralis (Boisd.) (Lepidoptera: Noctuidae) üzerine etkilerinin belirlenmesi. M.Sc. Thesis, Süleyman Demirel University, Isparta, Turkey

Dhanapal R, Kumar DSR, Lakshmipathy R, Rani CS, Kumar VM (2020) Exploration of indigenous strains of the green muscardine fungus from soils and their pathogenicity against the tobacco caterpillar, Spodoptera litura (Fabricius) (Lepidoptera: Noctuidae). Egypt J Biol Pest Control 30(1):1-5. https://doi.org/10.1186/s41938-020-00239-8

El-Hawary FM, Abd El-Salam AME (2009) Laboratory bioassay of some entomopathogenic fungi on Spodoptera littoralis (Boisd.) and Agrotis ipsiIon (Hufn.) larvae (Lepidoptera: Noctuidae). Egypt Acad J Biol Sci 2(2):1-4. https://doi.org/10.21608/eajbsf.2009.17547

El-Katatny $\mathrm{MH}$ (2010) Virulence potential of some fungal isolates and their control-promise against the Egyptian cotton leaf worm, Spodoptera littoralis. Arch Phytopathol Plant Prot 43(4):332-356. https://doi.org/10. 1080/03235400701806278

El Husseini MM (2019) Efficacy of the entomopathogenic fungus, Metarhizium anisopliae (Metsch.), against larvae of the cotton leaf worm, Spodoptera littoralis (Boisd.) (Lepidoptera: Noctuidae), under laboratory conditions. Egypt J Biol Pest Control 29(1): 50. https://doi.org/10.1186/ s41938-019-0156-2

Fite T, Tefera T, Negeri M, Damte T, Sori W (2020) Evaluation of Beauveria bassiana, Metarhizium anisopliae, and Bacillus thuringiensis for the management of Helicoverpa armigera (Hubner) (Lepidoptera: Noctuidae) under laboratory and field conditions. Biocontrol Sci Technol 30(3):278-295. https://doi.org/10.1080/09583157.2019.1707481

Güney E, Adıgüzel A, Demirbağ Z, Sezen K (2019) Bacillus thuringiensis kurstaki strains produce vegetative insecticidal proteins (Vip 3) with high potential. Egypt J Biol Pest Control 29(1):1-6. https://doi.org/10.1186/ s41938-019-0180-2

Kılıç E, Güven O, Baydar R, Karaca I (2019) The mortality effects of some entomopathogenic fungi against Helicoverpa armigera, Spodoptera littoralis, Tenebrio molitor and Blattella germanica. Kafkas Univ Vet Fak Derg 25(1):33-37. https://doi.org/10.9775/kvfd.2018.20278

Kim S, Kim JC, Lee SJ, Lee MR, Park SE, Li D, Kim JS (2020) Soil application of Metarhizium anisopliae JEF-314 granules to control, flower chafer beetle. Protaetia Brevitarsis Seulensis Mycobiology 48(2):139-147

Kulkarni SA (2015) Biochemical and molecular studies of chitin deacetylase from Metarhizium species. Ph.D Thesis, Savitribai Phule Pune University, India

Mishra S, Kumar P, Malik A (2015) Effect of temperature and humidity on pathogenicity of native Beauveria bassiana isolate against Musca domestica L. J Parasit Dis 39(4):1-8. https://doi.org/10.1007/s12639-013-0408-0

Ortiz-Urquiza A, Keyhani NO (2013) Action on the surface: Entomopathogenic fungi versus the insect cuticle. Insects 4(3):357-374. https://doi.org/10. 3390/insects4030357

Wan H (2003) Molecular biology of the entomopathogenic fungus Beauveria bassiana: Insect-cuticle degrading enzymes and development of a new selection marker for fungal transformation. Ph. D Thesis, Combined Faculties for the Natural Sciences and for Mathematics of the Ruperto-Carola University of Heidelberg, Germany.

Zimmermann G (1986) The 'Galleria bait method'for detection of entomopathogenic fungi in soil. J Appl Entomol 102(1-5):213-215. https://doi.org/10. 1111/j.1439-0418.1986.tb00912.x

\section{Publisher's Note}

Springer Nature remains neutral with regard to jurisdictional claims in published maps and institutional affiliations. 